Provided for non-commercial research and education use. Not for reproduction, distribution or commercial use.

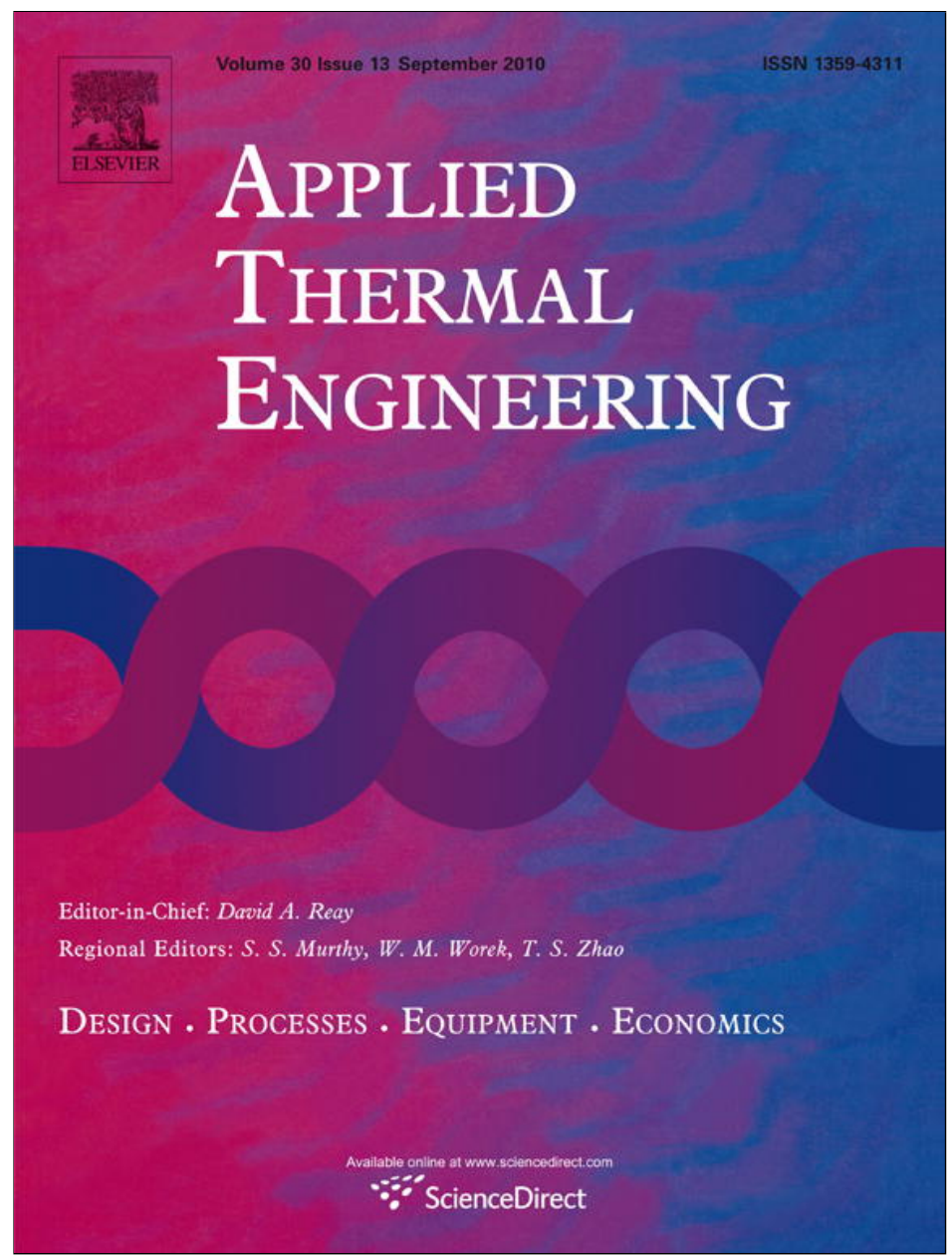

This article appeared in a journal published by Elsevier. The attached copy is furnished to the author for internal non-commercial research and education use, including for instruction at the authors institution and sharing with colleagues.

Other uses, including reproduction and distribution, or selling or licensing copies, or posting to personal, institutional or third party websites are prohibited.

In most cases authors are permitted to post their version of the article (e.g. in Word or Tex form) to their personal website or institutional repository. Authors requiring further information regarding Elsevier's archiving and manuscript policies are encouraged to visit:

http://www.elsevier.com/copyright 


\title{
Biomass fired hot air gas turbine with fluidized bed combustion
}

\author{
M. Gaderer ${ }^{\mathrm{a}, \mathrm{b}, *}$, G. Gallmetzer ${ }^{\mathrm{b}}, \mathrm{H}$. Spliethoff ${ }^{\mathrm{a}, \mathrm{b}}$ \\ ${ }^{a}$ Technische Universität München, Institute for Energy Systems, Boltzmannstr. 15, D-85747 Garching, Germany \\ ${ }^{\mathrm{b}}$ ZAE Bayern, Bavarian Center for Applied Energy Research, Division Technology for Energy Systems and Renewable Energy, Walther-Meißner-Str. 6, D-85748 Garching, Germany
}

\section{A R T I C L E I N F O}

\section{Article history:}

Received 10 November 2008

Accepted 8 March 2010

Available online 16 March 2010

\section{Keywords:}

High temperature heat exchanger

External firing

Immersed structured tube

Micro-turbine

Biomass

CHP

Combined heat and power

Hot air gas turbine

Indirect fired gas turbine

Small-scale power production

\begin{abstract}
A B S T R A C T
The prevailing demand for decentralized energy supply out of renewable energy sources, such as biomass, requires small-scale CHP technologies. Current developments at the Institute for Energy Systems, Technische Universität München, comprise the biomass fired hot air gas turbine, a fluidized bed wood combustor with integrated high temperature heat exchanger out of structured steel tubes for indirect firing of micro-turbines at $100 \mathrm{kWel}$. The fluidized bed consists of small particles $(<400 \mu \mathrm{m})$ and is fluidized at low gas velocities $(u<0.2 \mathrm{~m} / \mathrm{s})$, which cause high heat transfer numbers and low tube wall erosion rates.
\end{abstract} (c) 2010 Elsevier Ltd. All rights reserved.

\section{Introduction}

The availability of solid biomass fuels is restricted because of a limited availability and energy yield per hectare. Transportation of these fuels over a long-distance is not economic due to its low energy density. Therefore, a sustainable use of solid biomass fuels demands the application of micro scale and small-scale combined heat and power plants in the range of $10 \mathrm{kWel}$ to several MWel. For it, different concepts at small scale are available which are based on solid biomass combustion (Table 1). One solution is the external biomass fired hot air gas turbine (HGT) with fluidized bed combustion. This paper presents a work about the HGT process under the use of a fluidized bed combustion and an approach for the heat transport problem of HGT at the high temperature heat exchanger with structured steel tubes. The suggested solution should help to overcome specific problems of HGT like large heat exchanger areas and ash slagging.

\section{State of the art}

For the production of electricity power at small scale, following technical concepts are available, sorted by the state of the art and development of the technology (Table 1).

\footnotetext{
* Corresponding author at: Technische Universität München, Institute for Energy Systems, Boltzmannstr. 15, D-85747 Garching, Germany. Tel.: +49 8928916272 , +49 89289 16292; fax: +498928916271.

E-mail address: gaderer@tum.de (M. Gaderer).
}

As shown in Table 1 for the most concepts the availability on the market and the long time operation experience are low. This is surprising in fact, because especially in Germany and some other European countries exists a rather high demand for it. Due to the poor database, an economic comparison is very difficult. In Table 2 an economic approach for the HGT is presented, based on the German regulations. For the economic calculation, it was assumed that the HGT is operated in a typical German biomass power plant to produce base load heat for district heating. Especially full load hours, electrical and thermal efficiency (equivalent to revenues for power and heat) and fuel cost affect the economic calculation (Fig. 2). Especially in the range of 100-500 kWel, low priced wood chips as fuel and high waste heat temperatures the external fired HGT process is of interest (Fig. 1). The HGT offers high temperature heat with its flue gas of $>200{ }^{\circ} \mathrm{C}$ to increase the number of potential applications like district heating, cooling with an absorption chiller or the drive of a bottom cycle.

By replacing the combustion chamber of a gas turbine with a high temperature heat exchanger, the electrical efficiency of a solid biomass fuelled power plant can be increased from 15-20\% to 25-30\% (cf. [1] Kautz, 2004, [2] Kautz, 2005). The main reasons, why HGT do not succeed until now are the high necessary air temperature of $>850{ }^{\circ} \mathrm{C}$, ash sintering, slagging and fouling, material problems on the heat exchanger due to the low heat transfer of flue gas to air, large heat exchanger areas particularly in 
Table 1

Small-scale power production based on biomass ( + enough, $\bigcirc$ medium, - fail).

\begin{tabular}{|c|c|c|c|c|}
\hline & $\begin{array}{l}\text { Size } \\
\text { kWel }\end{array}$ & $\begin{array}{l}\text { el. Efficiency \% } \\
\text { based on fuel } \\
\text { LHV }\end{array}$ & $\begin{array}{l}\text { Availability \& } \\
\text { operation } \\
\text { experience }\end{array}$ & $\begin{array}{l}\text { Availability e.g. } \\
\text { company name }\end{array}$ \\
\hline Organic Rankine Cycle & $6-2.000$ & $10-15$ &,$+>200 \mathrm{kWel}$ & $\begin{array}{l}\text { Turboden, Italy } \\
\text { GMK, Germany } \\
\text { Adoratec, Germany }\end{array}$ \\
\hline Steam piston engine & $25-200$ & $8-14$ & 0 & Spilling Energie Systeme, Germany \\
\hline Stirling engine & $1-35$ & $5-20$ & - & $\begin{array}{l}\text { Stirling, Denmark } \\
\text { Sunmachine, Germany }\end{array}$ \\
\hline Steam screw engine & $1-700$ & $8-12$ & - & Köhler \& Ziegler, Germany \\
\hline $\begin{array}{l}\text { Gas piston engine based } \\
\text { on biomass gasification }\end{array}$ & $20-2.000$ & $10-36$ & + & $\begin{array}{l}\text { GE Jenbacher, Austria } \\
\text { Several other companies }\end{array}$ \\
\hline $\begin{array}{l}\text { Micro-turbine based on } \\
\text { biomass gasification }\end{array}$ & $30-100$ & $8-23$ & - & Turbec, Italy \\
\hline $\begin{array}{l}\text { External fired hot air } \\
\text { gas turbine }\end{array}$ & $50-100$ & $8-25$ & - & Talbotts, UK \\
\hline $\begin{array}{l}\text { SOFC/MCFC fuel cell based } \\
\text { on biomass gasification }\end{array}$ & $1-250$ & $20-50$ & - & MTU, Germany \\
\hline
\end{tabular}

combination with grate furnaces and a low number of available turbines.

One shaft micro-turbines have proved suitable for the hot air gas turbine process. A screening of research and development activities throughout Europe showed that current HGT pilot plants in generally make use of biomass combustion on grate furnaces and smoke tube heat exchangers (cf. [3] Gallmetzer, 2006). The turbine exhaust gas is used as combustion air for full recuperation of the turbine exhaust waste heat. This, in return, leads to an increased excess air ratio in the combustion chamber of approx. $\lambda=2.5$, resulting in a large exhaust gas mass stream at temperatures

\section{Table 2}

Economic approach based on VDI 2067 - "Economic efficiency of building installations, Fundamentals and economic calculation" and the German renewable energy law (EEG) regulations.

\begin{tabular}{|c|c|c|}
\hline Interest & & $6.00 \%$ \\
\hline Time (year ... y) & & $20 \mathrm{y}$ \\
\hline Annuity & & $8.72 \%$ \\
\hline Plant (HGT) & & $520.000 €$ \\
\hline Transport, start-up & & $15.000 €$ \\
\hline Buildings, fuel-storage, planning, etc. & & $100.000 €$ \\
\hline Total investment & & $635.000 €$ \\
\hline Specific costs & & $7.056 € / \mathrm{kWel}$ \\
\hline Power Pel & & $90 \mathrm{~kW}$ \\
\hline Efficiency $\eta \mathrm{el}$ & & $20 \%$ \\
\hline Heat $P$ th & & $300 \mathrm{~kW}$ \\
\hline Efficiency $\eta$ th & & $67 \%$ \\
\hline Fuel demand & & $450 \mathrm{~kW}$ \\
\hline Total efficiency $\eta$ & & $87 \%$ \\
\hline Fuel costs & & $13.5 € / \mathrm{MWh}$ \\
\hline Revenues power (German EEG, 2011) & & $22.2 \mathrm{ct} / \mathrm{kWh}$ \\
\hline Revenues heat (district heating, base load) & & $35.0 € / \mathrm{MWh}$ \\
\hline Full load operating hour (oh) & & $5.500 \mathrm{~h} / \mathrm{y}$ \\
\hline Produced heat & & $1.650 \mathrm{MWh} / \mathrm{y}$ \\
\hline Produced power & & $495.000 \mathrm{kWh} / \mathrm{y}$ \\
\hline Personal costs operation & $400 \mathrm{~h} / \mathrm{y}$ & $12.000 € / \mathrm{a}$ \\
\hline Operating media & $0.50 \%$ & $3.175 € / \mathrm{a}$ \\
\hline Maintenance & $2.50 \%$ & $15.875 € / \mathrm{a}$ \\
\hline Insurance & $1.00 \%$ & $6.350 € / \mathrm{a}$ \\
\hline Operation costs & $6.80 € / \mathrm{oh}$ & $37.400 € / y$ \\
\hline Capital costs & & $55.362 € / y$ \\
\hline Fuel costs & & $33.413 € / y$ \\
\hline Total costs & & $126.175 € / y$ \\
\hline Revenues power el & & $109.989 € / y$ \\
\hline Revenues heat & & $57.750 € / y$ \\
\hline Total revenues & & $167.739 € / y$ \\
\hline Gain & & $41.564 € / y$ \\
\hline Heat generation costs & & $9.8 € / \mathrm{MWh}$ \\
\hline
\end{tabular}

$>300^{\circ} \mathrm{C}$. With this cycle layout, an electrical efficiency in the range of $17-20 \%$ is possible (Talbotts Ltd., cf. [4] Pritchard, 2005). The heat transfer coefficient $k$ of the gas-to-gas high temperature heat exchanger is in the range of approx. $10 \mathrm{~W} / \mathrm{m}^{2} \mathrm{~K}$ (cf. [5] Pritchard, 2002), which indicates a low material efficiency of the high temperature heat exchanger tubes.

To increase the electrical efficiency up to the range of 30\%, a smallscale Organic Rankine Cycle (ORC) in the exhaust air mass stream after the turbine can be used (Ökozentrum Langenbruck, cf. [6] Schmid, 2006) without increasing the specific investment cost of approx. $4.500 € / \mathrm{kWel}$. The $\mathrm{R} \& \mathrm{D}$ screening revealed major research necessity in optimizing the performance and cost effectiveness of the biomass combustion chamber and high temperature heat exchanger.

\section{Related work on external firing of biomass in gas turbines}

A general status to external firing of biomass is given by Bram and J. De Ruyck, 2005 [15], especially focused on plants $>500 \mathrm{kWel}$ like the Siebenlehn plant in Germany. Since the end of the 90s, the ATZ-EVUS, Germany, developed a concept with a so-called Pebble Heater as regenerative heat exchanger (cf. [16], Stevanovic, 2001). As plant size of $500 \mathrm{kWel}$ up to $3 \mathrm{MWel}$ could be possible. For $<500 \mathrm{kWel}$ this could be a too complicated technology. Focused on the range of $<100 \mathrm{kWel}$ Talbotts Ltd., UK developed in 2005 a system based on a grate furnace combined with a micro-turbine from Bowman (cf. [4,5] Pritchard). Focused on thermodynamic and process simulation, work was done e.g. at the KTH, Stockholm by Wolf et al. [17] for a new top cycle, in Rostock at the IEUT by Hansen $[18,19]$ for a $100 \mathrm{kWel}$ system based on combustion and by Gangulya and Sarkara [20] for an HGT with integrated gasifier. Traverso

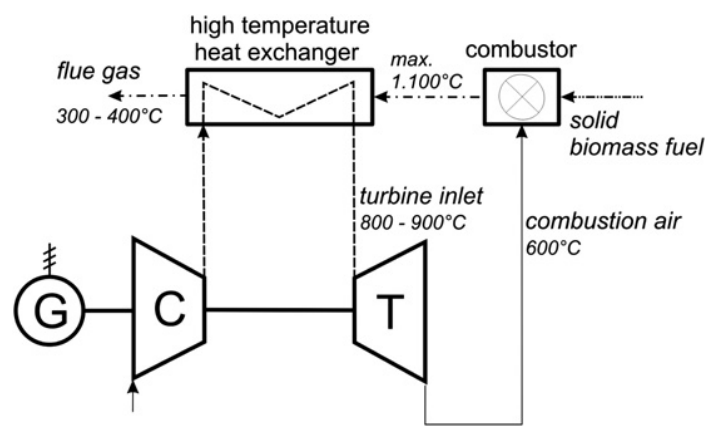

Fig. 1. Process flow diagram of the externally fired hot air gas turbine (HGT). 


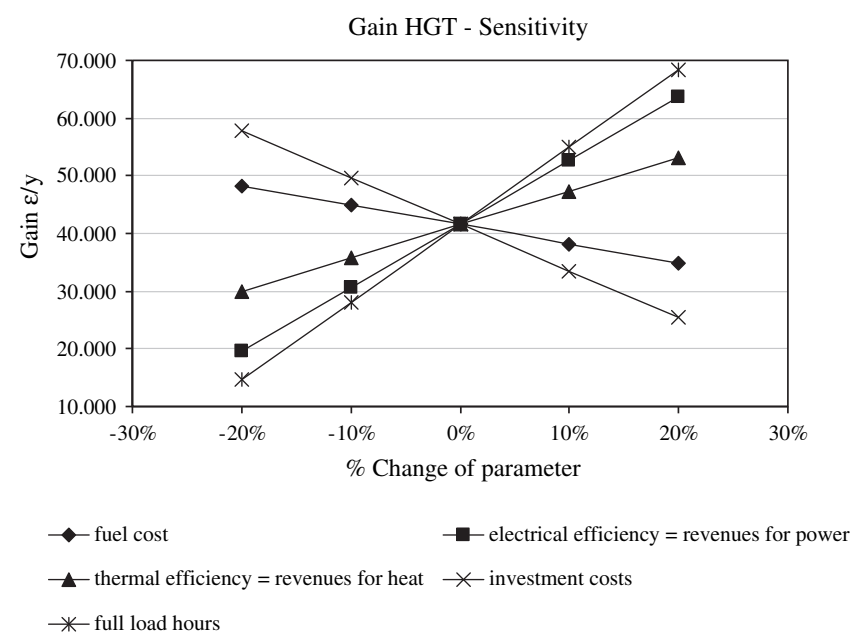

Fig. 2. Sensitivity of the gain affected by different parameters.

et al. [23] was working on control systems for an HGT process for $80 \mathrm{kWel}$ in households. Fischedick et al. [21] at the DLR in Stuttgart and Hiller et al. [22] at the TU Dresden did work based on the development of high temperature heat exchangers for an HGT process out of ceramic. No publications until now in the field of HGT in combination with small-scale fluidized bed combustion and immersed tubes are known.

\section{Technical concept for the heat exchanger}

The subject of the present work is the investigation of two different design concepts for the high temperature heat exchanger including bubbling fluidized bed combustion. The concepts are based on the increase of the heat transfer and reduction of slagging and fouling. The different heat exchanger concepts are described in Sections 4.1 and 4.2. Furthermore, a freeboard heat exchanger for heat recovery from the combustion chamber exhaust gas will be discussed. Simulation and experiment results will be presented and a design recommendation will be discussed below.

Cycle analysis of the biomass fired HGT via the process simulation tool IPSEpro revealed the need for a high turbine inlet temperature

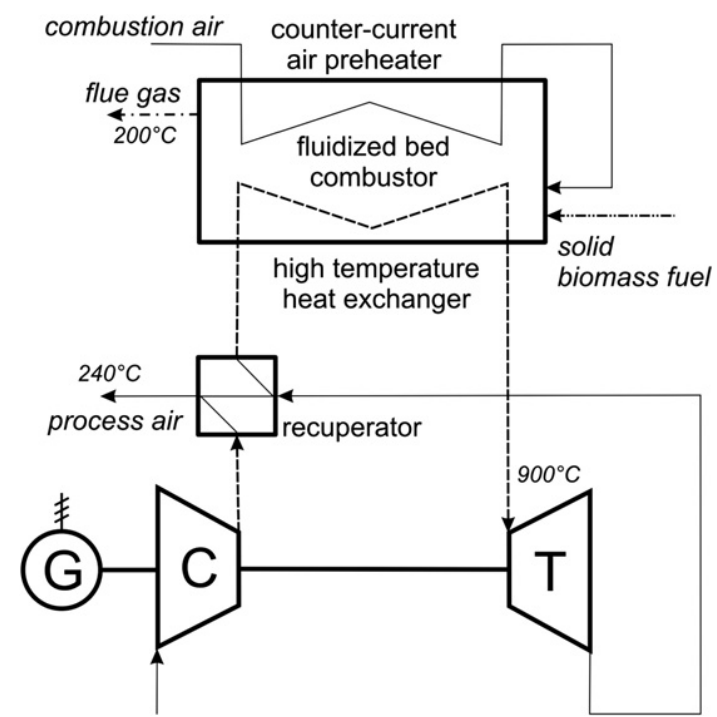

Fig. 3. Process flow diagram of the biomass fired hot air gas turbine with fluidized bed combustion. with a high grade of heat recuperation for achieving electrical efficiencies in the range of $30 \%$ without ORC bottom cycle (Fig. 3 ).

Because of fuel ash sintering, temperatures in the biomass combustor of the HGT are limited to a maximum of approx. $1.100^{\circ} \mathrm{C}$. Metallic heat exchanger tube wall temperatures are limited to approx. $925{ }^{\circ} \mathrm{C}$ because of material stability. High cost and low durability due to fouling erosion and corrosion of the heat exchanger tube wall material require a high performance heat exchanger design with low material effort.

The proposal comprises the integration of a vertically immersed tube heat exchanger into a fluidized bed combustion chamber. This design resulted from the adaptation of the heat capacity streams for optimum heat transfer conditions within the hot air gas turbine process. It includes several advantages.

$\bigcirc$ Heat flux is maximized when heat capacity streams within the counter-current heat exchangers are similar in magnitude.

$\bigcirc$ Low excess air ratio and high combustion air preheating possible due to cooling of the combustion chamber through heat release to the immersed tubes within the fluidized bed.

$\checkmark$ High heat transfer coefficients within the fluidized bed provide a large zone for heat transfer in the range of the highest process temperatures.

$\bigcirc$ Permanent particle convection minimizes fouling and, thus, corrosion at the surface of the immersed tubes.

Design parameters of the immersed tube heat exchanger and operating parameters of the fluidized bed combustor consider heat transfer coefficients; tube wall erosion rates, heat release rates and combustion properties of solid biomass fuels (cf. [7] Ottmann, M., 2007). Several measures should be applied, to minimize material wear due to erosion (cf. [8] Oka, S.N., 2004). They comprise vertical immersion of tube bundles for minimizing the particle collision impetus, fluidization gas velocity $u<0.2 \mathrm{~m} / \mathrm{s}$, use of e.g. olivine with small particle sizes $d_{\mathrm{P}}<400 \mu \mathrm{m}$ for sufficient fluidization at low gas velocities, use of chromium rich austenitic steel for an increased oxide layer shielding and air excess ratio $\lambda>1$ for a sufficient oxygen partial pressure that ensures a stable oxide layer at the tube wall. Further, tube bundles in tightly packed arrangements will limit bubble growth and, thus, bubble rise velocity that is considered as one of the main causes for erosion. Following these measures, material wear rate is estimated to a maximum in the range of $1 \mathrm{~mm} / 10^{4} \mathrm{~h}$, but only long term experiments would provide reliable data.

The IPSEpro-Cycle analysis of the HGT process points out the importance of systematic design of the high temperature heat exchanger. It is characterized by pressure loss $\Delta p$ and heat conductance $k \times A$. Measurements at the University of Rostock with smooth tube and structured tube high temperature heat exchangers showed an overall heat transfer coefficient of $k \approx 30 \mathrm{~W} / \mathrm{m}^{2} \mathrm{~K}$ for smooth tubes and $k \approx 50 \mathrm{~W} / \mathrm{m}^{2} \mathrm{~K}$ for structured tubes (cf. [2] Kautz, 2005). In both cases, a gas-to-gas heat exchanger has been used. Taking advantage of the high heat transfer coefficients of immersed tubes within a small particle fluidized bed in the range of $\alpha_{\mathrm{fb}}=700-800 \mathrm{~W} / \mathrm{m}^{2} \mathrm{~K}$, the heat conductance value $k \times A$ of the high temperature heat exchanger can be largely improved, without increasing the pressure loss $\Delta p$ of the gas flow. Two design concepts for the high temperature heat exchanger have been analyzed and evaluated and will be discussed below.

\subsection{Finned heat pipe heat exchanger}

The principle of the finned heat pipe heat exchanger consists of an improved heat conductance value $k \times A$ by an increase in heat transfer area $A$ at the tube to pressurized gas heat transfer. The 
availability of space in the fluidized bed for an increased heat transfer area is low. Hence, heat is transferred via high heat conductance heat pipes into a pressure tank. The heat releasing condenser of the heat pipes within the pressure tank is finned with circular fins to provide sufficient surface for the area intensive heat transfer to the pressurized gas of the HGT. Mathematical modelling of the finned heat pipe heat exchanger showed heat conductance values in the range of $k \times A=3 \mathrm{~kW} / \mathrm{K}$ with a heat transfer area of $60 \mathrm{~m}^{2}$. Pressure loss within the finned heat pipe heat exchanger is not a major issue.

The finned heat pipe heat exchanger requires a relatively large volume within the pressure tank. High material costs for the thickwalled high temperature pressure tank and poor availability of high temperature heat pipes are the main disadvantages that led to the conclusion not to favour this option.

\subsection{Structured tube wall heat exchanger}

The principle of the structured tube wall heat exchanger consists of an improved heat conductance by an increase of the gas to tube wall heat transfer coefficient. Heat exchanger tubes are vertically immersed in the fluidized bed. Heat is transferred from the fluidized bed through the tube wall into the pressurized gas.

The tube to gas heat transfer coefficient dominates heat transfer. It differs in approx. one order of magnitude from the fluidized bed heat transfer coefficient. An immersed tube heat exchanger with smooth tube walls would require an elevated number of immersed tubes and, hence, exceed the maximum tube density $\mu$ within the fluidized bed. Cycle and material efficiency can be improved by an increase in the inner gas to tube wall heat transfer coefficient.

The tube walls can be structured by cold deformation to show an axially recurring pattern of radial dents (Figs. 4 and 5). These dents force a thinner boundary layer in the gas flow and cause an increase in the average heat transfer number of up to $150 \%$ in comparison to smooth tube walls (e.g. [9] Mitrovic, J., 2004). Dent depth has a major impact on the heat transfer performance, but there are little data available about a correlation of structured tube wall geometry and heat transfer performance.

A CFD simulation has been carried out to visualize and understand the influence of the tube wall geometry on the gas flow and to determine the overall pressure loss and local heat transfer coefficients. The structured surfaces of a series of tubes with different dent depths have been captured to a digital model by an optical three-dimensional scan. The CFD calculation applied the boundary conditions of the HGT process streams and temperatures. The influence of the tube wall geometry on the local heat flux density can be shown (Fig. 4) to range over one order of magnitude. The average heat flux shows an increase of the overall heat transfer coefficient. It can be explained by following effects:

The gas velocity at the dent tube wall is much higher than the average (Fig. 5). This decreases the height of the gas boundary layer at the tube wall and, hence, increases the heat flux through it.

Enhanced turbulence of the gas flow causes an increased mass transport of gas from the hot tube wall to the cooler core flow of the tube and, hence, increases heat flux.

$\bigcirc$ Repeating simultaneous hydrodynamic and thermal onset of flow with the length $x$ after every dent, contained in the tube. The effect could be described with the generalized Lévêque equation for $\mathrm{Nu}$ (Eq. (1)) ([10] VDI-Wärmeatlas, 2002).

$$
\mathrm{Nu}_{\mathrm{m}}=0.5384\left(\frac{\operatorname{HgPr} D_{\mathrm{T}}}{4 x}\right)^{1 / 3}
$$

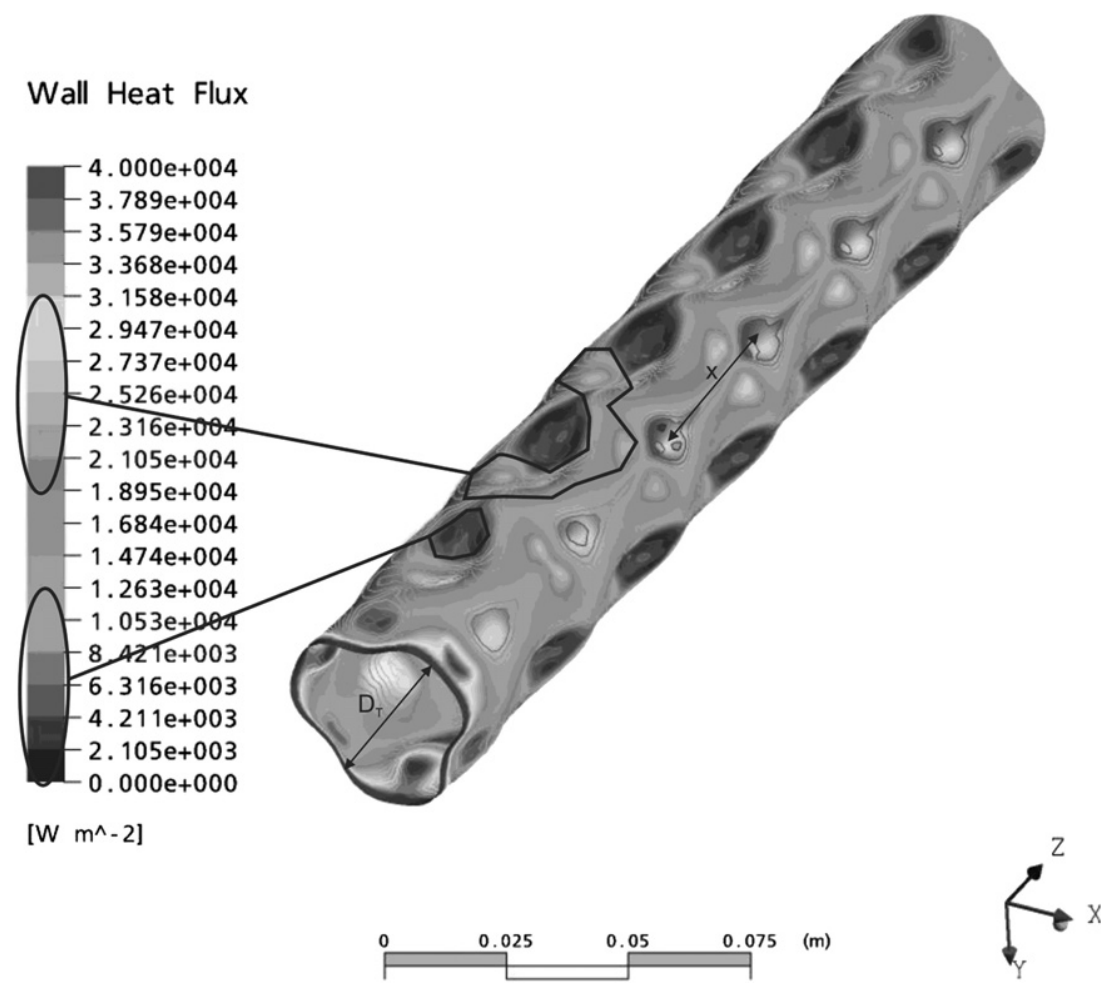

Fig. 4. Simulation results of the local heat flux density through a structured tube wall with $5.25 \mathrm{~mm}$ dent depth, $x \ldots$ region of hydrodynamic and thermal onset of flow, $D_{\mathrm{T}} \ldots$ tube diameter. 


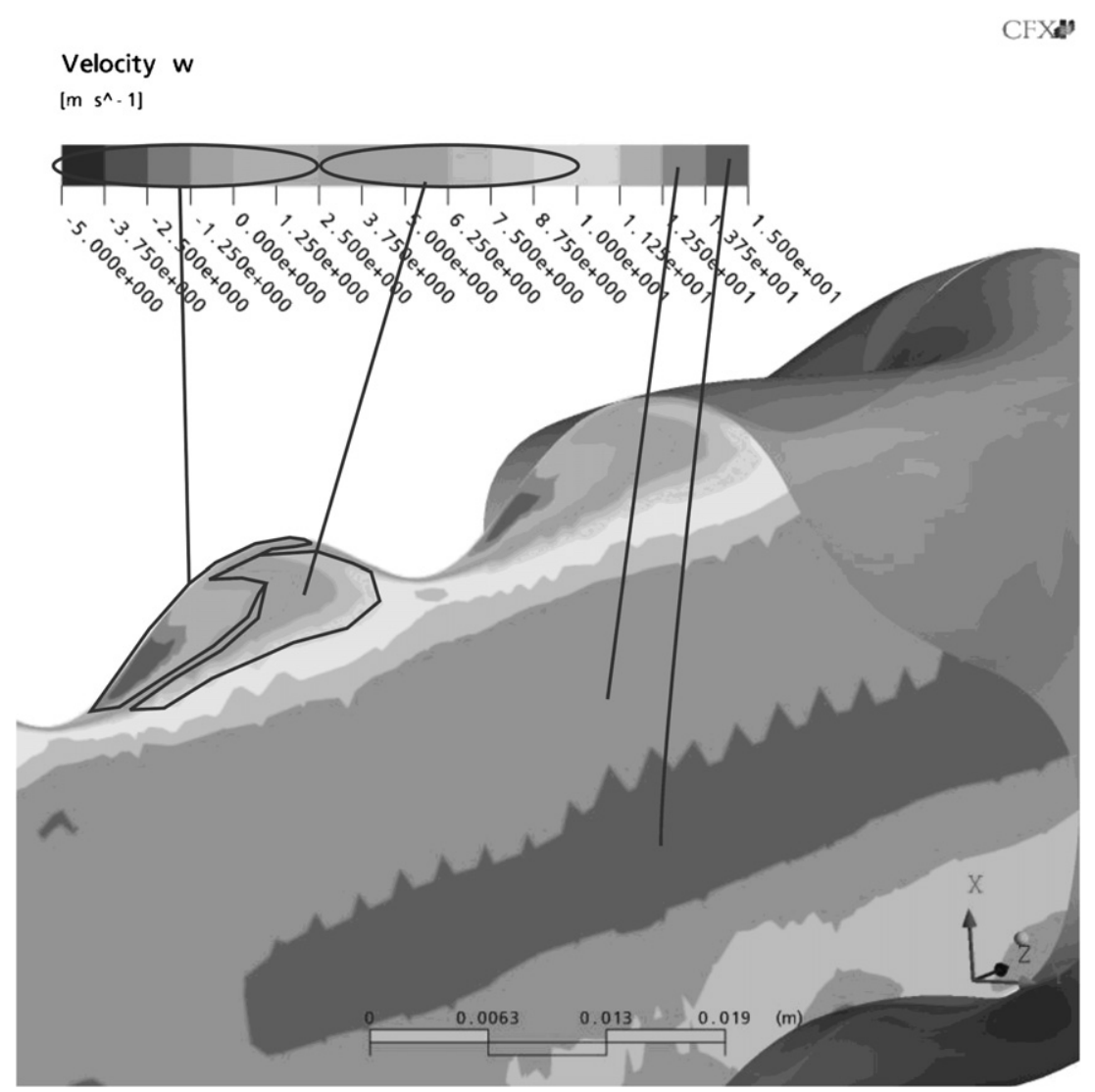

Fig. 5. Simulation results of the averaged local gas velocity in a structured tube wall with $6 \mathrm{~mm}$ dent depth and $40 \mathrm{~mm}$ inner diameter.

Higher turbulence and high local gas velocities cause an increased flow resistance of the structured tube. By structuring of the tube surface, heat transfer can be greatly improved, but pressure drop of the gas flow along the structured tubes increases, too. An instrument for evaluating the overall gain is the Performance Evaluation Criteria PEC (cf. [11] Webb, R.L., 1992). It is a measure for evaluating the quality of the gas flow including the gain in heat transfer and the increase in pressure drop and pumping power respectively (Fig. 6).

$\mathrm{PEC}=\frac{\left(\mathrm{St}_{\text {structured tube }} / \mathrm{St}_{\text {smooth tube }}\right)^{3}}{\zeta_{\text {structured tube }} / \zeta_{\text {smooth tube }}}[-], \mathrm{St}=\mathrm{Nu}_{\mathrm{m}} /(\mathrm{Re} \cdot \mathrm{Pr})$

St is the Stanton number, a measure for heat transfer, calculated from the heat flux results; $\zeta$ is the average friction factor of the gas

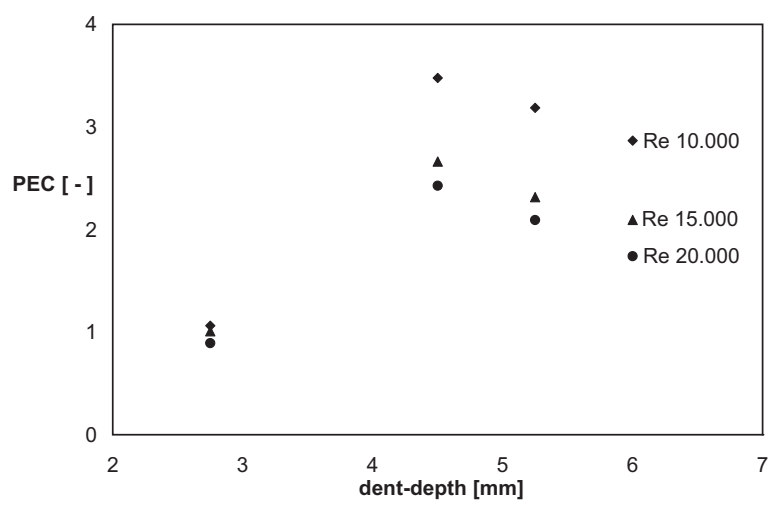

Fig. 6. Performance Evaluation Criteria PEC for the evaluation of heat transfer gain with different dent depths in the structured tube wall with a diameter of $40 \mathrm{~mm}$. flow, calculated from the pressure loss results of the CFD simulation. The dent depth of the structured tube and the Reynolds number are the main parameter for influencing heat transfer and pressure loss. Fig. 6 shows the correlation of the PEC with the dent depth at different flow conditions. At dent depths below $3 \mathrm{~mm}$ and $15 \%$ of the tube radius respectively there can be seen no gain in flow quality. A clear maximum in flow quality is achieved at a dent depth of $4.6 \mathrm{~mm}$ and $23 \%$ respectively. It decreases sharply with further increase in dent depth. Different flow conditions have no influence on the position of the maximum at the dent depth of $23 \%$ of the tube radius but clearly show the best quality of gas flow at the Reynolds number $\operatorname{Re}=10^{4}$.

Overall heat transfer coefficient values $k$ in the range of $150 \mathrm{~W} / \mathrm{m}^{2} \mathrm{~K}$ can be achieved. The heat conductance value $k \times \mathrm{A}$ of the high temperature heat exchanger can be doubled from 1 to $1.5 \mathrm{~kW} / \mathrm{K}$ for smooth tubes to $2-3 \mathrm{~kW} / \mathrm{K}$ using structured tubes. The impact on the HGT process is an increase in turbine inlet temperature and, thus, an increase in electrical efficiency in the range of $3-5$ percentage points with a raise of the investment costs below $1 \%$.

\section{Experimental results}

5.1. Heat transfer coefficient in fluidized bed with packed arrangement of heat exchanger tubes

Solid particle dispersion within the bubbling fluidized bed combustion chamber is impeded by a packed arrangement of vertical tubes. Based on experimental results from different authors and his own theoretical examination of the process of solid particle mixing, M.O. Todes suggested, that the order of magnitude of solid particle axial dispersion is proportional to $L^{3 / 2}$ where $L$ is the characteristic dimension of the bed, e.g. the horizontal pitch of the 
vertical tubes ([12] Todes, M.O., 1981). Hence, a reduced vertical dispersion rate in the biomass combustion chamber would lead to an elevated temperature gradient between the lower bed and the bed surface, where char combustion takes place. Therefore, the particles in the lower bed region would lose their sensible heat to the heat exchanger and undercool, whereas the upper bed region would overheat and run the risk of ash agglomeration. This correlation leads to the assumption that a maximum tube density $\mu$ within the fluidized bed is critical for heat transfer and save operation of the combustion chamber.

$\mu=1-\frac{A_{\text {tube bundle }}}{A_{\text {total }}}[-]$

During experiments (cf. [13] Metz, 2007) this value has been estimated to $\mu=0.85$, equivalent to a minimum average horizontal pitch of $S_{\mathrm{h}}=50 \mathrm{~mm}$ with tubes of $33.7 \mathrm{~mm}$. Further experiments have shown that the horizontal pitch of heat exchanger tubes is a key parameter for influencing heat transfer to immersed tube bundles (cf. [14] Gel'perin and Ainstein, 1971).

$\mathrm{Nu}_{\mathrm{p}, \text { max }}=0.75 \operatorname{Ar}^{0.22}\left(1-\frac{D_{\mathrm{T}}}{S_{\mathrm{h}}}\right)^{0.14}, \quad S_{\mathrm{h}} / D_{\mathrm{T}}=1.25-5$

The axial and radial deformation of structured tubes can have a relevant influence on heat transfer and particle dispersion in the fluidized bed. Due to the relevance of this cognition concerning the design of the immersed tube heat exchanger, further investigations have been carried out. The experiments were performed in a cold model BFB unit with a diameter of $0.4 \mathrm{~m}$ and a height of $0.6 \mathrm{~m}$.

The probes consisted of $40 \mathrm{~mm}$ diameter tubes with smooth surface, axially knurled structured surface (Fig. 7) and structured surface with an axially recurring pattern of radial dents (Figs. 4 and 5). Probes were surrounded by an annulus of smooth tubes with flexible horizontal pitch. Experimental results (Fig. 8) show, that there is a relevant change in heat transfer coefficient with the horizontal pitch. Within a tolerance of $\pm 10 \%$ expression Eq. (4) could be confirmed. Radially structured tubes (Figs. 4 and 5) showed no relevant effect on the heat transfer coefficient. However, axially knurled tubes (Fig. 7) showed a decrease in heat transfer coefficient of $20-40 \%$ compared with radially structured and smooth tubes.

Their gain in heat transfer area of $41 \%$ is partly compensated by low particle heat transfer coefficients at low horizontal tube distances. The reason may be shading of the inner triangle area from particle convection by the limitation of bubble size and, thus, bubble rise velocity at low tube distances. However, heat transfer through radiation is not affected by tube spacing of the heat exchanger. At a bed temperature of $900^{\circ} \mathrm{C}$ heat transfer takes place

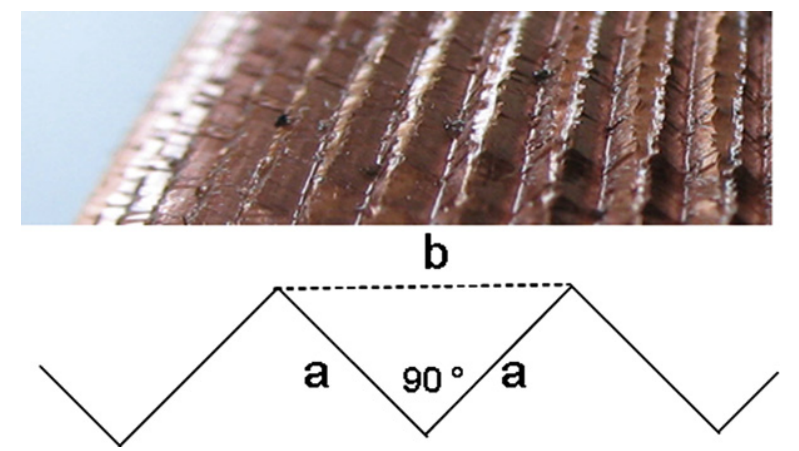

Fig. 7. Close-up of the surface structure of axially knurled tubes. By cold deformation, an orthogonal triangle structure can be applied to the surface resulting in a surface area increase of $41 \%$ with $b=2 \mathrm{~mm}$.

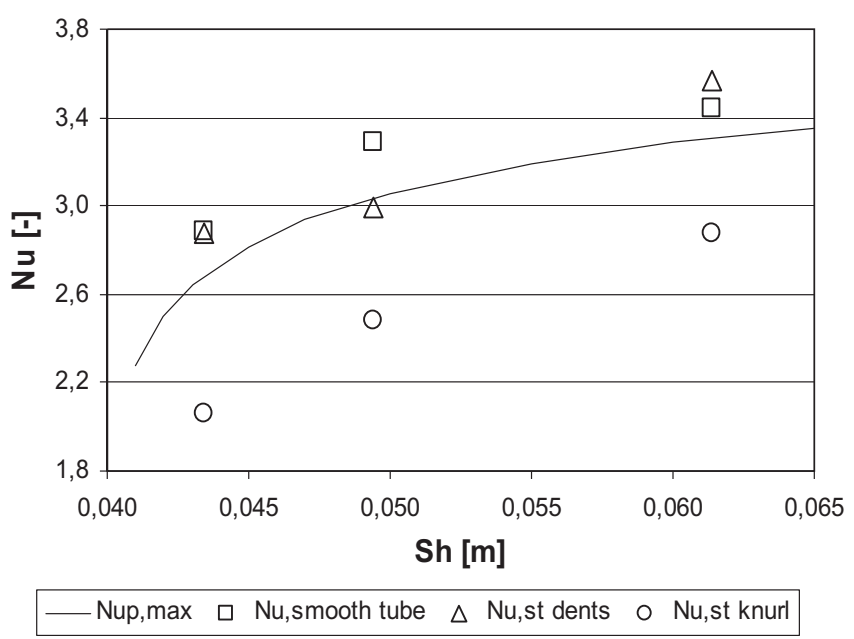

Fig. 8. Heat transfer influenced by distance between tubes for smooth tubes, structured tubes with dents and structured tubes with axial knurl compared with data from literature (Eq. (4)).

by radiation to a relevant extend of $30-50 \%$. This part can fully be increased by the factor of surface area gain of axially knurled tubes.

\section{Conclusions}

The integration of a high temperature heat exchanger into a fluidized bed biomass combustion chamber allows a high performance hot air gas turbine cycle with moderate material effort. Computational fluid dynamic simulation has shown that the quality of gas flow through the heat exchanger tubes can be improved by a factor of $2-3.5$ by radial deformation of the tube surface. The maximum flow quality is achieved at a dent depth of approx. $23 \%$ of the tube radius.

The horizontal pitch of heat exchanger tubes is limited to a minimum of approx. $50 \mathrm{~mm}$. Experiment results approved the decrease in heat transfer coefficient with decreasing horizontal pitch. Though, radially structured tubes showed no difference compared with smooth tubes, axially knurled tubes showed a superposed effect of surface shading at small horizontal pitches.

\section{Acknowledgement}

This work was supported by the Bayerisches Staatsministerium, Regierung von Unterfranken, Projekt Nr. 300-3400.00-4/05 IBG-HTW

\section{Notation}

$\begin{array}{ll}A & \text { cross sectional area, } \mathrm{m}^{2} \\ \mathrm{Ar} & \text { archimedes number, }- \\ d_{\mathrm{P}} & \text { average bed particle size, } \mu \mathrm{m} \\ D_{\mathrm{T}} & \text { tube diameter, } \mathrm{m} \\ \mathrm{el} & \text { electricity } \\ \mathrm{Hg} & \text { hagen number, }- \\ k & \text { overall heat transfer coefficient, } \mathrm{W} / \mathrm{m}^{2} \mathrm{~K} \\ k \times A & \text { heat conductance, } \mathrm{W} / \mathrm{K} \\ L & \text { length, } \mathrm{m} \\ \mathrm{LHV} & \text { lower heating value } \\ \mathrm{Nu} & \text { nusselt number, }- \\ \mathrm{Nu} & \text { maximum particle Nusselt number, - } \\ \mathrm{PEC} & \text { performance Evaluation Criteria, } \\ \mathrm{Pr} & \text { prandtl number, }- \\ \mathrm{Re} & \text { reynolds number, }-\end{array}$


stanton number, -

$S_{\mathrm{h}} \quad$ horizontal pitch, $\mathrm{m}$

$u \quad$ fluidization gas velocity, $\mathrm{m} / \mathrm{s}$

$x \quad$ region of hydrodynamic and thermal onset of flow, $\mathrm{m}$

$\alpha_{\mathrm{fb}} \quad$ heat transfer coefficient in fluidized bed, $\mathrm{W} / \mathrm{m}^{2} \mathrm{~K}$

$\lambda \quad$ excess air ratio, -

$\mu \quad$ tube density, -

\section{References}

[1] M. Kautz, DGMK Tagungsbericht 2004-1, April 2004, S. 129-136, 2004

[2] M. Kautz, Diss. Auslegung von extern gefeuerten Gasturbinen für dezentrale Energieanlagen im kleinen Leistungsbereich, 2005.

[3] G. Gallmetzer, ZAE Symposium, Konzepte zur Realisierung indirekt mit Biomasse befeuerter Heißluftturbinen, http://www.zae-bayern.de, 2006.

[4] D. Pritchard, Biomass Fuelled Indirect Fired Micro Turbine, DTI/Pub URN 05 698,2005

[5] D. Pritchard, Biomass Combustion Gas Turbine CHP, DTI/Pub URN 02/1346, 2002

[6] M. Schmid, Biomass Compact Combined Cycle (2006).http://www. oekozentrum.ch.

[7] M. Ottmann, Diss., Combustion of Biogenous Fuels in Fluidized Bed Combustors. Technische Universität München, Lehrstuhl für Energiesysteme, 2007.

[8] S.N. Oka, Fluidized Bed Combustion, ISBN: 0-8247-4699-6, 2004.

[9] J. Mitrovic, Heat Exchanger and Condenser Tubes, ISBN: 3-934736-08-4, 2004

10] VDI-Wärmeatlas, 9. Auflage, (Chapter A2), Springer-Verlag Berlin, Heidelberg (2002)

[11] R. Webb, Principles of Enhanced Heat Transfer. John Wiley \& Sons, New York USA, 1992, ISBN 0-471-57778-2.

[12] M.O. Todes, Reactors with Coarse Particle Fluidized Beds, 1981 (in Russian)

[13] Th. Metz, Allotherme Vergasung von Biomasse in indirekt beheizten Wirbelschichten. Fortschritt-Berichte VDI, Reihe 6, Energietechnik. Dissertation, 2007, 554 pp.
[14] N.I. Gel'perin, V.G. Ainstein, Heat transfer in fluidized beds. in: J.F. Davidson, D. Harrison (Eds.), Fluidization, first ed. Academic Press, London, 1971, pp. 471-540.

[15] S. Bran, J. De Ruyck, Status of external firing of biomass in gas turbines. IMechE: Journal of Power and Energy. ISSN: 0957-6509 219 (2005). ISSN: 0957-6509 (Print-Version) 2041-2967 (Online-Version), pp. 137-147.

[16] D. Stevanovic, Innovative Biomass Power Plant Based on Pebble-heater Technology and Hot Air Turbine, ATZ-EVUS, Power-Gen 2001, Brussels, 2001.

[17] J. Wolf, F. Barone, Y. Yan, Performance analysis of evaporative biomass air turbine cycle with gasification for topping combustion KTH, Stockholm. Journal of Engineering for Gas Turbines and Power 124 (2002) 761.

[18] U. Hansen, M. Kautz, Simulation von extern gefeuerten Gasturbinen (EFGTCycle) VDI-Tagung Fortschrittliche Energiewandlung und -anwendung, VDIBericht 1746. Universität Rostock, Institut für Energie- und Umwelttechnik IEUT, Stuttgart, 2003.

[19] U. Hansen, M. Kautz The externally-fired gas-turbine (EFGT-Cycle) for decentralized use of biomass University of Rostock, Institute of Energy Systems. Applied Energy 84 (7-8) (2007) 795-805.

[20] R. Gangulya, L. Sarkara, Energy and exergy analyses of an externally fired gas turbine (EFGT) cycle integrated with gasifier for distributed power generation Department of Power Engineering, Jadavpur University, India. Energy 35 (1) (2010) 341-350.

[21] S. Fischedick, V. Dreißigacker, R. Tamme, An innovative ceramic high temperature plate-fin heat exchanger for EFCC processes, DLR. Applied Thermal Engineering. ISSN: 1359-4311 27 (8-9) (2006). ISSN: 1359-4311 1285-1294. doi:10.1016/j.applthermaleng.2006.11.007 Elsevier Ltd.

[22] A. Hiller, J. Löser, Chr. Schmid, G. Nauditt, New possibilities for the application of ceramic heat exchangers in processes with high-temperatures and difficult atmospheres, TU-Dresden, in: S. 48 and Proceeding International Conference on Incineration \& Thermal Treatment Technologies - IT3, 12-16.05.2008, Montreal, Quebec, Canada, Heft 88 (2008), VGB-PowerTech 7, 2008.

[23] A. Traverso, A. Massardo, R. Scarpellini, Externally fired micro-gas turbine: modelling and experimental performance Thermochemical Power Group, Dipartimento di Macchine, Sistemi Energetici e Trasporti, Università di Genova. Applied Thermal Engineering 26 (16) (2006) 1935-1941. 